\title{
Arctic Air Cooler
}

Josef Soukup ${ }^{1}$, Petr Přibil ${ }^{2}$ Blanka Skočilasová ${ }^{1}$,

${ }^{1}$ Faculty of Production Technology and Management, J. E. Purkyne University in Usti nad Labem. Pasteurova 3334/7, 40001 Usti nad Labem, Czech Republic.E-mail: soukupj@fvtm.ujep.cz, skocilasova@fvtm.ujep.cz

${ }^{2}$ Bronswerk Heat Transfer Ltd., Benešov nad Ploučnicí., Děčínská 288, 40722 Benešov n. Pl., Czech Republic. petr.pribil@bronswerk.cz

The article deals with the design of a process recirculation air cooler for cooling natural gas when the latter is processed. The cooler is intended for extreme climatic conditions, and due to this reason, it is necessary when designing and fabricating the cooler to comply with the specific requirements for both the calculation and materials to be used on constructing it. In the winter period when the ambient temperature drops even below the solidification point of the medium the cooler works with reduced rpm of the fan, and when necessary, even in the recirculation mode, partial or full (depending on the ambient temperature). In this case, the inlet and outlet louvers are closed, and the recirculation louvers are opened. This system allows, using the control of the temperature of the inlet cooling air, to maintain the temperature of the cooled medium at the desired level.

Keywords: air cooler, recirculation, tube bundle, thermal design quation

\section{Acknowledgement}

The article originated under the support of the grant SGS UJEP and the company Bronswerk Heat Transfer spol. s $r$. o., Benešov nad Ploučnicí.

\section{References}

[1] VAMPOL, J. (1969). Air cooled exchangers. Summary of design data. SVÚSS.

[2] DVOŘÁK, Z. (1990). Heat sharing by heat exchangers. ČVUT Praha.

[3] FRAAS, A., P, OZSIK, M, N. (1965). Heat exchanger design. John Wiley \& Sons New York.

[4] KRÖGER, D.G. (1998). Air-cooled Heat Exchanger and Cooling Towers. MIT.

[5] CHLUMSKÝ, V. (1971). Technique of cooling. SNTL Praha.

[6] PŘIBIL, P. (2015). Design of a recirculation air cooler. Diploma Thesis. FVTM UJEP.

[7] ŠAPOŠNIKOV, V. (1977). Atmospheric coolers and air towers. SNTL Praha.

[8] NOŽIČKA, J. (1997). Heat sharing. ČVUT Praha.

[9] SKOČILASOVÁ, B., SKOČILAS, J. (2013). Simulation of liquid flow in pipe. Manufacturing Technology, vol. 13, no 4, p542-547, ISSN 1213-2489

[10]ASME CODE Sec. VIII, div 1.

[11]GOST R (certification system of products for the Russian Federation)

[12]API STANDARD 661 (Standard for designing air cooler)

[13]ČSN EN 14986 (design of fans for work in explosion risk environment)

[14]http://www.bronswerk.cz 